\title{
Genetic Variability and Heritability in Sugarcane
}

\author{
Rewati R Chaudhary \\ Sugarcane Research Programme, Nepal Agricultural Research Council, Jitpur, Bara
}

\begin{abstract}
Thirty-two genotypes were evaluated in a replicated trial at Sugarcane Research Program, Jitpur, Bara, Nepal in 2000-2001 to estimate phenotypic and genotypic coefficients of variation, heritability and genetic advance for seven stalk characters in sugarcane (Saccharum officinarum L). Analysis of variance revealed highly significant differences between genotypes for all the characters studied. Genotypic variance was higher than environmental one for cane yield, millable cane number, single cane weight, stalk diameter and stalk length. A single cane weight, germination at 45 days after planting and millable cane number had high genotypic and phenotypic coefficients of variation. High heritability estimates were recorded for millable cane number, stalk diameter and single cane weight. Maximum genetic gain as percent of mean was observed for single cane weight and millable cane number.
\end{abstract}

Key words: Genetic advance, genetic variability, heritability, sugarcane

\section{Introduction}

Sugarcane varieties in commercial cultivation are complex polyploid. The heterozygous and polyploid nature of this crop have resulted in generation of greater genetic variability. The information on the nature and the magnitude of variability present in the genetic material is of prime importance for a breeder to initiate any effective selection program. Genotypic and phenotypic coefficients of variation along with heritability as well as genetic advance are very essential to improve any trait of sugarcane because this would help in knowing whether or not the desired objective can be achieved from the material (Tyagi and Singh, 1998). The present study was, therefore carried out to know the nature and extent of genetic variability, heritability and genetic advance in some important traits of sugarcane.

\section{Materials and Methods}

The experimental material for the present study consisted of 32 genotypes of sugarcane including four standard checks viz. BO 99, BO 102, BO 91 and $\operatorname{CoS} 767$ representing early, mid and late maturing groups (Annex 1). Sugarcane was planted in ring method with three replications at the farm of Sugarcane Research Program, Jitpur, Bara, Nepal during Feb 2000. The crop received $150 \mathrm{~kg} \mathrm{~N}, 60 \mathrm{~kg}$ $\mathrm{P}_{2} \mathrm{O}_{5}$ and $40 \mathrm{~kg} \mathrm{~K}_{2} 0 \mathrm{ha}^{-1}$. All agronomical practices were adopted during the entire crop season. Data were recorded on germination percentage at 45 days after planting (DAP), millable cane number, stalk diameter, stalk length, single cane weight, sucrose content and cane yield (Annex 1).

Analysis of variance was used for calculating genotypic, phenotypic and environmental characters. The broad sense heritability was estimated according to the method suggested by Johnson et al. (1955) and the expected genetic advance was calculated by the method given by Robinson et al. (1949).

\section{Results and Discussion}

The analysis of variance for all the characters showed that genotypes included in the test differed significantly $(\mathrm{p} \leq 0.01)$ with respect to all characters studied (Table 1). This indicates that there was significant amount of phenotypic variability and all the genotypes differed each other with regard to the characters that opened a way to proceed for further improvement through simple selection (Punia, 1982). 
Table 1. Analysis of variance for seven stalk characters in 32 sugarcane genotypes grown at the farm of Sugarcane Research Program, Jitpur, Nepal during 2000/2001

\begin{tabular}{lcccccccc}
\hline Source & $\mathrm{df}$ & $\begin{array}{c}\text { Cane } \\
\text { yield }\end{array}$ & $\begin{array}{c}\text { Millable } \\
\text { cane number }\end{array}$ & $\begin{array}{c}\text { Single cane } \\
\text { weight }\end{array}$ & $\begin{array}{c}\text { Stalk } \\
\text { diameter }\end{array}$ & $\begin{array}{c}\text { Stalk } \\
\text { length }\end{array}$ & $\begin{array}{c}\text { Germination } \\
\text { at 45 DAP } \dagger\end{array}$ & Sucrose \\
\hline Replications & 2 & 19.84 & 16.86 & 0.0017 & 0.0108 & 436.02 & 7.868 & 0.811 \\
Genotypes & 31 & $219.04^{* *}$ & $2817.45^{* *}$ & $0.094^{* *}$ & $0.025^{* *}$ & $1918.8^{* *}$ & $160.96^{* *}$ & $20.087^{* *}$ \\
Error & 62 & 33.58 & 117.3 & 0.005 & 0.0092 & 215.95 & 75.39 & 8.334 \\
\hline
\end{tabular}

** Significant at $1 \%$ level; $\uparrow$ DAP, Days after planting.

Mean values for cane yield varied between $30.8 \mathrm{t} \mathrm{ha}^{-1}$ in clone Co 94024 and $86.67 \mathrm{t} \mathrm{ha}^{-1}$ in clone CoSe 95422 (Annex 1). Millable cane varied from 73000 in clone BO 99 to 158000 in clone CoSe 95422. Single cane weight varied from $0.35 \mathrm{~kg}$ in clone Co 94024 to $0.64 \mathrm{~kg}$ in clone CoB 94162. The clone Co92031 was the tallest $(221 \mathrm{~cm})$, while the clone Co 94023 was the shortest $(133 \mathrm{~cm})$ in stalk length. Likewise sucrose content varied from $17.56 \%$ in the clone CoP 92181 and $21.4 \%$ in the clone $\mathrm{CoB}$ 94162 (Annex 1).

\section{Genotypic and phenotypic coefficients of variation}

After partitioning phenotypic variance, it was found that genotypic variance was higher than the environmental one for five characters studied (Table $2)$. The magnitude of variance was the highest in millable cane $\left(\sigma_{\mathrm{g}}^{2}=900.05, \sigma_{\mathrm{e}}^{2}=117.3\right)$ followed by stalk length $\left(\sigma_{\mathrm{g}}^{2}=567.61, \sigma_{\mathrm{e}}^{2}=215.95\right)$. These results indicate that a negligible role was played by the environmental factors in the inheritance of these characters in sugarcane. The high genotypic variance for millable cane was reported also by other researchers (Balasundarum and Bhagyalakshmi, 1978; Nair et al., 1980).

Table 2. Components of variances, coefficients of variation, heritability, genetic advance for seven stalk characters in sugarcane genotypes grown at Jitpur, Nepal in 2000/2001

\begin{tabular}{lccccccc}
\hline Component $\dagger$ & Cane yield & Millable cane & $\begin{array}{c}\text { Single cane } \\
\text { weight }\end{array}$ & Stalk diameter & $\begin{array}{c}\text { Germ 45 } \\
\text { DAP }\end{array}$ & Stalk length & Sucrose \\
\hline PCV, \% & 19.4 & 29.18 & 41.52 & 14.64 & 32.56 & 15.48 & 18.33 \\
$\mathrm{GCV}, \%$ & 15.63 & 27.44 & 38.01 & 13.54 & 21.86 & 13.17 & 10.37 \\
$\sigma_{\mathrm{p}}^{2}$ & 95.4 & 1017.35 & 0.0346 & 0.062 & 137.24 & 783.56 & 12.25 \\
$\sigma_{\mathrm{g}}^{2}$ & 61.82 & 900.05 & 0.029 & 0.053 & 61.85 & 567.61 & 3.92 \\
$\sigma_{\mathrm{e}}^{2}$ & 33.58 & 117.3 & 0.005 & 0.009 & 85.39 & 215.95 & 8.334 \\
$\mathrm{H}, \%$ & 65 & 88 & 84 & 85 & 45 & 72 & 32 \\
$\mathrm{GAdv}, \%$ & 25.98 & 52.9 & 70.0 & 25.58 & 30.19 & 38.15 & 12.08 \\
\hline
\end{tabular}

$\dagger$ PCV, Phenotypic coefficient of variation; GCV, Genotypic coefficient of variation; $\sigma_{\mathrm{p}}^{2}$, Phenotypic variance; $\sigma_{\mathrm{g}}^{2}$, Genotypic variance; $\sigma_{e}^{2}$, Environment variance; $H$, Heritability percentage; GAdv, Genetic advance.

$\ddagger$ Germ 45 DAP, Germination at 45 days after planting.

The estimates for phenotypic coefficient of variation (PCV) were higher than for genotypic coefficient of variation $(\mathrm{GCV})$ in all the traits, indicating greater influence of environment on genetic variation. The highest phenotypic and genotypic coefficient of variation were observed for single cane weight $(\mathrm{PCV}=41.52 \%, \mathrm{GCV}=38.01 \%)$ followed by germination at $45 \mathrm{DAP}(\mathrm{PCV}=32.56 \%, \mathrm{GCV}=$ $21.86 \%)$ and millable cane number $(\mathrm{PCV}=29.18 \%$ and $\mathrm{GCV}=27.44 \%$ ). High genotypic and phenotypic coefficients of variation for a single cane weight and millable cane number were reported earlier by Singh and Sangwan (1980).

\section{Heritability}

Genotypic coefficient of variation is not a correct measure to know the heritable variation present and should be considered together with heritability estimates. In the present experiment, high heritability estimates were recorded for millable cane number $(88 \%)$, stalk diameter $(85 \%)$ and a single cane weight (84\%). This suggests that simple selection for these traits would be effective. It is 
reported that a high heritability estimate for single cane weight (Nair et al., 1980; Singh et al., 1994). Moderate values for heritability estimates were found in stalk length (72\%) and cane yield (65\%), whereas, low heritability estimates were observed in germination at 45 days after planting $(45 \%)$ and sucrose percent (32\%). Similar results were obtained by Sahi et al. (1977) for juice quality characters. Selections might be considerably difficult or virtually impractical for a character with low heritability (less than 0.4 ) due to the masking effect of environment on genotypic effects (Singh, 1993).

\section{Genetic advance}

Heritability estimates along with expected genetic gain is more useful than the heritability value alone in predicting the resultant effect for selecting the best genotypes (Johnson et al., 1955). Maximum genetic gain (as percent of mean) was observed for a single cane weight $(70 \%)$ followed by millable cane number $(52.9 \%)$ indicating that there exists a scope to improve cane yield to a considerable extent by adopting suitable breeding procedures. High genetic advance (as percent of mean) for single cane weight was also reported by Sahi et al. (1977), Tyagi and Singh (1998). Stalk diameter had high heritability with moderate genetic advance. Pandey (1989) had earlier reported the low genetic advance with moderate to high amount of heritability for stalk diameter suggesting a little scope in the improvement of this character.

The results suggest that selection should be practiced on the basis of single cane weight and millable cane number for higher cane yield. Improvement in these traits would lead to a significant improvement in yield in limited selection cycles.

\section{Acknowledgements}

Thanks are due to KP Mahato, Senior Scientist, Sugarcane Research Program, Jitpur for cooperation in conducting the field research and BK Joshi, Scientist, Agriculture Botany Division, Khumaltar for his valuable help in correcting and making the manuscript in this shape.

\section{References}

Balasundarum, N and KV Bhagyalkshmi. 1978. Variability, heritability and association among yield and yield components in sugarcane. Indian J. Agric. Sci. 48:291-295.

Johnson, HW, HF Robinson and RE Comstock. 1955. Estimates of genetic and environmental variability in soybean. Agron. J. 47: 314-318.

Nair, NV, KG Somarajan and N Balasundaram. 1980. Genetic variability, heritability and genetic advance in Saccharum officinarum. Int. Sugarcane J. XXX I I: 275-276.

Pandey, RA. 1989. Variability study in the hybrid progenies of sugarcane (Saccharum complex). Bhartiya Sugar (Oct.):49-51.

Punia, MS. 1982. Studies on variability, heritability and genetic advance of some quality attributes in sugarcane. Indian Sugar 31:911-914.

Robinson, HF, RE Comstock and PH Harvey. 1949. Estimates of heritability and degree of dominance in corn. Agron. J. 41:353-359.

Sahi, BK, SS Shah and KA Patel. 1977. Variability in early varieties of sugarcane in plant and ratoon crops. Indian J. Genet. Plant. Breed. 37:496-500.

Singh, R and RS Sangwan. 1980. Studies on genetic variability for stalk characters in sugarcane. Indian Sugar 30:409-412.

Singh, RK, DN Singh, SK Singh and HN Singh. 1994. Genetic variability and correlation studies in foreign commercial hybrids of sugarcane. Agric. Sci. Dig., Karnal 14:103-107.

Singh, BD. 1993. Plant Breeding. 5th ed. Kalyani Publishers, Rajender Nagar, Ludhiana, India, pp. 102, 104.

Tyagi, SD and DN Singh. 1998. Studies on genetic variability for stalk characters in sugarcane. Indian Sugar XL VIII:259-262. 
Nepal Agric. Res. J., Vol. 4 \& 5, 2000/2001

Annex 1. Sugarcane yield and its attributes as affected by different genotypes

\begin{tabular}{|c|c|c|c|c|c|c|c|c|}
\hline SN & Genotype & $\begin{array}{c}\text { Cane } \\
\text { yield, } \mathrm{t} \mathrm{ha}^{-1}\end{array}$ & $\begin{array}{l}\text { Single cane } \\
\text { weight, kg }\end{array}$ & $\begin{array}{c}\text { Stalk } \\
\text { length, } \mathrm{cm}\end{array}$ & $\begin{array}{c}\text { Stalk } \\
\text { diameter, } \mathrm{cm}\end{array}$ & $\begin{array}{c}\text { Germination at } \\
45 \mathrm{DAP} \uparrow, \%\end{array}$ & $\begin{array}{c}\text { Millable cane } \\
\text { number, '000 ha }\end{array}$ & $\begin{array}{c}\text { Sucrose, } \\
\%\end{array}$ \\
\hline 1 & Co 92030 & 50.72 & 0.41 & 174 & 1.95 & 34.6 & 129 & 19.50 \\
\hline 2 & Co 92031 & 36.50 & 0.40 & 221 & 1.81 & 23.5 & 85 & 19.14 \\
\hline 3 & Co 94022 & 42.35 & 0.39 & 163 & 1.72 & 40.8 & 117 & 19.40 \\
\hline 4 & Co 94023 & 34.45 & 0.37 & 133 & 1.63 & 41.4 & 89 & 18.72 \\
\hline 5 & Co 94024 & 30.83 & 0.35 & 189 & 1.87 & 25.6 & 97 & 18.93 \\
\hline 6 & CoP 92181 & 50.21 & 0.43 & 186 & 1.78 & 35.4 & 117 & 17.46 \\
\hline 7 & BO 130 & 63.56 & 0.58 & 197 & 1.85 & 46.7 & 113 & 19.83 \\
\hline 8 & CoB 94161 & 40.78 & 0.46 & 185 & 1.75 & 34.8 & 116 & 19.50 \\
\hline 9 & CoB 94162 & 55.49 & 0.64 & 192 & 1.86 & 35.7 & 83 & 21.41 \\
\hline 10 & CoSe 95421 & 51.26 & 0.36 & 198 & 1.48 & 49.2 & 137 & 18.98 \\
\hline 11 & CoSe 95422 & 86.67 & 0.51 & 204 & 1.83 & 46.4 & 158 & 18.50 \\
\hline 12 & CoSe 91232 & 53.30 & 0.53 & 169 & 1.74 & 34.4 & 89 & 19.50 \\
\hline 13 & CoSe 96234 & 59.65 & 0.54 & 167 & 1.67 & 36.8 & 109 & 18.75 \\
\hline 14 & BO 131 & 63.20 & 0.53 & 175 & 1.69 & 31.1 & 111 & 19.40 \\
\hline 15 & BO 132 & 55.15 & 0.48 & 194 & 1.62 & 32.4 & 103 & 18.01 \\
\hline 16 & CoSe 95435 & 62.30 & 0.55 & 179 & 1.71 & 31.3 & 101 & 17.90 \\
\hline 17 & CoP 92184 & 53.82 & 0.52 & 178 & 1.73 & 33.2 & 105 & 19.20 \\
\hline 18 & CoP 92186 & 40.05 & 0.44 & 166 & 1.64 & 42.3 & 93 & 19.15 \\
\hline 19 & CoSe 92429 & 42.36 & 0.46 & 157 & 1.84 & 48.1 & 94 & 19.46 \\
\hline 20 & CoSe 92423 & 75.53 & 0.61 & 209 & 2.02 & 36.3 & 108 & 18.98 \\
\hline 21 & CoSe 92430 & 68.34 & 0.59 & 195 & 1.85 & 31.2 & 95 & 18.51 \\
\hline 22 & CoSe 92437 & 44.80 & 0.42 & 167 & 1.77 & 41.9 & 90 & 18.70 \\
\hline 23 & CoSe 92440 & 48.68 & 0.54 & 178 & 1.78 & 38.4 & 95 & 19.04 \\
\hline 24 & CoSe 92032 & 39.40 & 0.53 & 164 & 1.89 & 43.4 & 84 & 18.64 \\
\hline 25 & CoP 95181 & 51.12 & 0.55 & 215 & 1.79 & 29.7 & 93 & 17.85 \\
\hline 26 & CoP 95182 & 50.14 & 0.51 & 214 & 1.76 & 27.5 & 104 & 17.90 \\
\hline 27 & CoSe 93234 & 52.50 & 0.53 & 205 & 1.75 & 33.6 & 106 & 19.13 \\
\hline 28 & BO 99 & 53.45 & 0.36 & 165 & 1.64 & 35.3 & 73 & 17.84 \\
\hline 29 & BO 102 & 55.15 & 0.41 & 176 & 1.63 & 40.5 & 127 & 17.60 \\
\hline 30 & $\operatorname{CoS} 687$ & 38.39 & 0.38 & 168 & 1.70 & 31.1 & 99 & 18.67 \\
\hline 31 & BO 91 & 55.68 & 0.46 & 204 & 1.88 & 43.2 & 113 & 19.71 \\
\hline 32 & $\operatorname{CoS} 767$ & 36.67 & 0.47 & 213 & 1.70 & 32.5 & 78 & 17.78 \\
\hline
\end{tabular}

